\author{
Adam Pisarek \\ ORCID: 0000-0002-9872-364X \\ Uniwersytet Śląski w Katowicach
}

\title{
Nadpisywanie powierzchni
}

Ludwig Wittgenstein w Dociekaniach filozoficznych przyrównywał język do miasta: ,plątanina uliczek i placów, starych i nowych domów, domów z dobudówkami z różnych czasów; a wszystko to otoczone licznymi nowymi przedmieściami o prostych regularnych ulicach, ze standardowymi domami" ${ }^{1}$. Clifford Geertz wykorzystał tę samą metaforę do opisu myśli potocznej ${ }^{2}$. W jednym i drugim wypadku konkretny model przestrzenny posłużył za klucz organizujący wiedzę dotyczącą systemowego charakteru kultury w jej różnych aspektach. Podobnie jest z palimpsestem w tomie pod redakcją Anny Gomóły i Anny Szawerny-Dyrszki ${ }^{3}$. Podobnie, ale nie tak samo - poszczególne artykuły, a także ich wzajemne związki pokazują, jak dużo bardziej zawiłe są kulturowo konstruowane relacje pomiędzy miejscem, tekstem $\mathrm{i}$ językiem.

Pierwszy poziom, na którym w recenzowanym tomie rozpatrywany jest ów problem, przedstawiony został we wstępie. „Miejsca są jak palimpsesty i podobnie powstają"4 - twierdzą redaktorki, wskazując na wartość poznawczą organizującej książkę metafory. Interesuje je przede wszystkim to, w jaki sposób w kulturze europejskiej takie zestawienie mogło zostać pomyślane. Zwracają uwagę na sposoby manipulowania strukturami symbolicznymi, by były paralelne wobec systemu niesymbolicznego oraz odwrotnie - jak przebiegało manipulowanie tym, co niesymboliczne, w oparciu o utrwalone struktury znaczeń ${ }^{5}$. Kluczowe pod tym względem wydaje się dla autorek artykułu wstępnego spojrzenie na człowieka z obiektywizującej perspektywy geografii oraz zrozumienie podstawowych cech systemu przekodowań, które pozwalają na stworzenie mapy jako reprezentacji terytorium. Gomóła i Szawerna-Dyrszka (Poza geografia i historią. Palimpsest:

${ }^{1}$ L. Wittgentein, Dociekania filozoficzne, przeł. B. Wolniewicz, Warszawa 1972, s. 16.

2 C. Geertz, Myśl potoczna jako system kulturowy, [w:] idem, Wiedza lokalna. Dalsze eseje z zakresu antropologii interpretatywanej, Kraków 2005, s. 81.

${ }^{3}$ Palimpsest. Miejsca i przestrzenie, red. A. Gomóła, A. Szawerna-Dyrszka, Katowice 2018.

${ }^{4}$ Ibidem, s. 12.

${ }^{5}$ C. Geertz, Religia jako system kulturowy, [w:] idem, Interpretacja kultur. Wybrane eseje, przeł. M. Piechaczek, Kraków 2005, s. 115-116. 
miejsce i przestrzeń) zauważają przy tym, że taki „wycinek świata” ukrywa swój aspekt temporalny, a przecież zawsze jest produktem pewnego czasu.

Jeśli już jednak ustanowiono relację między przestrzenią a jej dwuwymiarową translacją jako możliwy sposób interpretowania wieloaspektowego doświadczenia przebywania w świecie, droga do tworzenia włączających dodatkowe czynniki modeli została otwarta. Palimpsest jako figura myślowa okazał się narzędziem, które stało się pomocne w praktykach interpretowania miejsc. Rękopis, przez który prześwitują kolejne warstwy inskrypcji, inaczej niż wspomniana wyżej mapa, pozwala bowiem unaocznić relacje diachronii w ramach synchronii. Pozwala także zwrócić uwagę na znaki przeszłości w teraźniejszości, a jednocześnie przybliża do siebie relacje przestrzenne i relacje tekstowe, stanowiąc sposób na wizualne przedstawienie tego, co temporalne. Daje także możliwość zorientowania w tym polu podmiotu, który staje się przede wszystkim czytelnikiem — interpretatorem.

Ostatni artykuł w tomie - autorstwa Galiny Kurylenko (Parki w Nieświeżu. Palimpsestowe sploty natury $i$ historii) — jest wzorcową próbą odczytywania miejsca jako takiego właśnie palimpsestu, przez który prześwitują różne warstwy historii tworzące współczesną topografię. Założenie parkowe pozwala poprzez miejsce opowiadać dzieje, a dzieje porządkować zgodnie z konstrukcją opisywanego skrzętnie parku - wszystko następuje zgodnie z logiką nadpisywania tekstu (w książce) na inny „tekst” (w Nieświeżu).

To jednak dopiero początek problematyzacji, którym podlega kwestia palimpsestowości przestrzeni i miejsca w omawianym tomie. Drugi i przedostatni artykuł stanowią szkice $\mathrm{z}$ archeologii symbolicznych form organizowania przestrzeni w naszej kulturze - są rodzajem metakomentarza do zaprezentowanych wyżej wątków. Karina Banaszkiewicz (Obraz w epoce przekaźników cyfrowo-falowych. Między palimpsestem a hybryda), zaznaczając, że do palimpsestu sięgamy, by „prze-pisywać i od-grywać przestrzeń”, zwraca uwagę na to, w jaki sposób współczesne rozumienie obrazu jest modelowane przez tę i podobne figury. $\mathrm{Na}$ styku porządku wizualności i języka szuka trwałych wzorców, które pozwalają na naturalizowanie i narratywizację przestrzeni w ramach współczesnych nośników komunikacji. Elżbieta Dutka skupia się natomiast przede wszystkim na zachodniej tradycji „czytania” konkretnych miejsc i — bardziej abstrakcyjnych — przestrzeni. Z jednej strony wtajemniczeni zostajemy w problematykę tekstu jako formy unaocznienia, wiążącej się z pytaniem o to, „w jaki sposób można pod warstwą słów dostrzec realną przestrzeń?" 6 . Z drugiej strony autorka omawia różne realizacje toposu interpretowania krajobrazu jako tekstu, pokazując kulturową trwałość tego wyobrażenia oraz szereg zmian zachodzących w jego ramach. Miejsce bywało bowiem traktowane jako powierzchnia, którą należy przeniknąć, by odsłonić kolejne warstwy znaczeń. Współcześnie staje się natomiast „proce-

${ }^{6}$ K. Banaszkiewicz, Obraz w epoce przekaźników cyfrowo-falowych. Między palimpsestem a hybryda, [w:] Palimpsest..., s. 200. 
sem, polem przepływów, mobilności, lokalizacji i dyslokacji”7. Zmienia się wizja świata, a razem z nią pojawia się dyskursywna potrzeba nowej metafory. Teksty Banaszkiewicz i Dutki tworzą w mojej opinii dyptyk niuansujący relacje między modelem wpisanym w medium a modelem rzeczywistości, który przy jego pomocy jest tworzony i odtwarzany.

Kolejne artykuły są analizami gier reprezentacji i kreacji, nadpisywania znaczeń w tekście i ich odczytywania w miejscu. Status przestrzeni ulega w nich szeregowi przekształceń - często okazuje się ona zapisem poddającym się praktykom lektury, ale zdarza się też tak, że to tekst staje się prawie realną przestrzenią. Zmieniają się media i konwencje - nie tylko literatura, ale także teatr, rzeźba i muzyka modelowane są według podobnego wzorca i uczestniczyć mogą w podobnej grze znaczeń. Zajmują pozycję pergaminu czekającego, aż ktoś go odczyta. Wyjątkowe miejsce w tomie, jeśli przyjmiemy taki klucz interpretacyjny, zajmuje artykuł Magdaleny Piotrowskiej-Grot (,Po drugiej stronie czasu”. Powrót jako kategoria negatywna (?) w poezji roczników siedemdziesiątych). W nim bowiem najwyraźniej wybrzmiewa wątek związków z miejscem i typów praktyk służących jego konceptualizacji. Pożegnania, powroty i eksploracje wydają się być poetyckimi formułami, które wprowadzają dynamikę w teksty opowiadające o czytaniu miejsc. Autorka analizuje zapisy, te zaś są obrazami przestrzeni, w które palimpsest nie jest wpisany bezpośrednio, lecz stanowi konsekwencję wrażliwości i działalności podmiotu.

Jeszcze inaczej palimspestowość rozumie Ewa Kosowska. Jej analiza konkretnej instytucji kulturowej przesuwa wszystkie pytania z poziomu reprezentacji na poziom funkcjonalizacji. To pozwala na przekroczenie ograniczeń organizującej tom metafory wpisującej historię w relacje przestrzenne. Działalność Polskiego Związku Kulturalno-Oświatowego w Czeskim Cieszynie i jego Sekcji Folklorystycznej staje się w oczach autorki raczej pisaniem palimpsestu - a analiza tego procesu daje wgląd w trwanie i zmianę kultury, w ramach której opisywana instytucja się kształtowała.

Nie mniej złożone gry zapośredniczeń są przedmiotem innych artykułów. Antonina Szybowska (Miasto i czarownica. W poszukiwaniu tożsamości miejsca), skupiając się na pomniku czeladzkiej czarownicy, z dokumentacyjnym pietyzmem rekonstruuje, jak współczesny artefakt staje się palimpsestem - tekstem kultury, przez który zaczyna prześwitywać dotąd ukryta historia miejsca. Beata Nowacka (Ćwiczenia pamięci. Na marginesie „Bitwy o Monte Cassino” Melchiora Wańkowicza) zafascynowana jest podobnym splotem. Palimpsest przyjmuje u niej formę „memorialnej mapy”, a historia, zgodnie z ustaleniami Pierre'a Nory, materializuje się jako miejsce.

${ }^{7}$ E. Dutka, ,,Za, a nawet przeciw”, czyli parę uwag i pytań o palimpsestowość miejsc i przestrzeni, [w:] Palimpsest..., s. 29. 
Katarzyna Niesporek inaczej buduje swój wywód — interesują ją poetyckie przedstawienia hałdy, wysypiska popiołów i żużlu, które są charakterystyczne dla przemysłowego Śląska. Jej analizy pozwalają dostrzec, jak blisko i nierozerwalnie są z sobą splecione różne formy mówienia i doświadczania miejsca. Jak konkretne elementy krajobrazu mogą być nasycane znaczeniami przez poezję i dopiero dzięki niej tworzyć rzeczywiste ślady przeszłości.

Potrzeba tworzenia i odnajdywania miejsc autobiograficznych jest także przedmiotem kolejnego artykułu (Bożena Szałasta-Rogowska, ,, Wynoszone z ciemności szkice węglem na skórze wydrapane”. O twórczości literackiej Romana Sabo). Zmienia się w nim jednak skala analizy. Doświadczenie indywidualne zostaje skonfrontowane z geografią wyobrażoną, którą można odczytywać jako „kolektywny" palimpsest - miejsce negocjacji pomiędzy literackimi obrazami a ideologią, zgodnie z którą strukturowana i wartościowana jest przestrzeń uznawana przez daną grupę za swoją. Również analiza twórczości Renaty Putzlacher-Buchtovej (w artykule Krystyny Kossakowskiej-Jarosz) służy ukazaniu tego, w jaki sposób literatura staje się witalną siłą w negocjowaniu znaczenia przestrzeni oraz w jaki sposób tworzone są w jej ramach złożone modele, które mogą następnie stać się bazowe dla wyobraźni społecznej. Kamila Czaja skupia się na podobnym zagadnieniu. Interesują ją jednak raczej wpisane w topos miasta i prowincji narracje wartościujące, które uaktualniają się raz za razem w reportażach Marcina Kołodziejczyka.

Elżbieta Grodzka-Łopuszyńska wykorzystuje natomiast kategorię palimpsestu, by mówić o partyturze - czyta ją jako odwzorowanie i jednocześnie świadectwo procesu twórczego. To dla niej przestrzeń zapisu, w której dzieło żyje i dzięki któremu ożywa. Również Dorota Fox łączy palimpsest z witalną siłą — przyglądając się podziemnym terenom zamkniętej kopalni i odbywającym się tam spektaklom grupy teatru site-specific, zauważa, w jaki sposób opowieść ożywia przestrzeń. Ta przestaje być tylko miejscem dla archeologa szukającego ledwie dostrzegalnych śladów przeszłości. Nasycone emocjami surowe wnętrza pomagają w konstytuowaniu się lokalnej wspólnoty. Spektakl tworzy nowy model odczytania relacji z miejscem i zarazem eksponuje jej palimpsestowy i więziotwórczy charakter.

Redaktorki trafnie ujęły w układzie tomu to, o czym piszą we wstępie. Palimpsest jest wyrazem, charakterystycznego dla naszej cyrograficznej kultury, myślenia nawarstwiającymi się reprezentacjami i związanymi z nimi wizualnymi i tekstowymi sieciami znaczeń. Nic więc dziwnego, że to właśnie on, na poziomie strukturalnym, nadaje spójność wielu, bardzo różnorodnym narracjom; zapewnia również spójność recenzowanego tomu. Jest przy tym modelem, który nie ma ambicji totalizujących — prowadzi ku badaniom rozproszonych znaczeń i gry ich warstwowo układających się sieci. Pozwala też na dalsze nadpisywanie i tworzenie kolejnych powierzchni, przez które prześwitują te wcześniejsze. Tak właśnie toczy się gra modeli służących ustanowieniu i usensowieniu relacji pomiędzy tym, co symboliczne, a tym, co przestrzenne. 